\title{
EFFECT OF VARIETY AND SEED RATE ON YIELD PERFORMANCE OF MUNGBEAN UNDER STRIP TILLAGE SYSTEM
}

\author{
Md. Moshiur Rahman ${ }^{1}$, Taslima Zahan ${ }^{2^{*}}$, MS Ali ${ }^{1}$, M Begum $^{1}$ and RW Bell ${ }^{3}$ \\ ${ }^{1}$ Bangladesh Agricultural University, Mymensingh, Bangladesh \\ ${ }^{2}$ Bangladesh Agricultural Research Institute, Gazipur, Bangladesh \\ ${ }^{3}$ Murdoch University, Australia \\ *Corresponding author: taslimazahan_tzp@yahoo.com
}

Key words: Seed rate, minimum tillage system, mungbean, machine seeding

\begin{abstract}
A study was conducted at Bangladesh Agricultural University, Mymensingh during March-June, 2013 to evaluate the performance of mungbean varieties and to determine the optimum seed rate under strip tillage system. Three mungbean varieties (BARI Mung-6, Binamung-5 and Binamung-8) were tested against five seeding rates $\left(20,25,30,35\right.$ and $\left.40 \mathrm{~kg} \mathrm{ha}^{-1}\right)$. The experiment was laid out in splitplot design with three replications. The study revealed that variety and seed rate had significant effect on plant population, pods plant ${ }^{-1}$, pod length, seeds pod $^{-1}$, seed yield and stover yield of mungbean. The highest seed yield was obtained from Bina mung-5 at $35 \mathrm{~kg}$ seed ha-1 while the highest stover yield was obtained from $40 \mathrm{~kg}$ seed ha ${ }^{-1}$. For BARI Mung- 6 and Binamung- $8,35 \mathrm{~kg}$ seed ha ${ }^{-1}$ also provided higher seed yield than other seeding rates. Nevertheless, the lowest seed and stover yields were obtained from Bina mung-8 with $20 \mathrm{~kg}$ seed ha- ${ }^{-1}$. Therefore, the study concluded that machine seeding of mungbean at $35 \mathrm{~kg}^{-1} \mathrm{Th}^{-1}$ ensure optimum seed yield for tested varieties under strip tillage system and cultivation of Bina mung5 at $35 \mathrm{~kg}$ seed ha ${ }^{-1}$ can produce the maximum seed yield under this system.
\end{abstract}

\section{Introduction}

Mungbean (Vigna radiata L.) is one of the most important pulse crops of Bangladesh. The total production of mungbean in Bangladesh was 32,000 metric tons from an area of 39,285 ha of land with average yield about $0.81 \mathrm{t} \mathrm{ha}^{-1}$ during 2013-14 (BBS, 2016). The crop has already been transformed from a marginal to major crop for its additional benefits like enhancing soil fertility, improving rural household income, employment opportunities, diversifying diets and increasing nutritional security (Shanmugasundaram et al., 2009). The short-growth duration variety of mungbean is well fitted in rice-based cropping systems of Asia. But our country is facing an acute shortage of mungbean due to low yield of $654.4 \mathrm{~kg}$ $\mathrm{ha}^{-1}$ (MOA, 2012) and less production area. The reasons of low yield may be lack of high yielding varieties and some agronomicmanagement practices.Generally mungbean is cultivated with conventional tillage that requires considerable fuel, labour and time. Besides conventional tillage leads to soil erosion resulting soil fertility depletion. On the other hand, strip tillage offers potential to reduce soil erosion though a narrow strip of about six inches wide and four to eight inches deep is made in a single pass that helps to conserve soil moisture and consequently ensures similar soil temperature to conventional tillage systems (Nowatzki et al., 2011; Endres and Hendrickson, 2010). Seeding of mungbean in a strip by a machine reduces use of fuel and production cost by reducing the number of field passes and additionally, fertilizer can be applied at the same time of seeding with same machine.

Seed rate is one of the most important factors to achieve satisfactory yield. Due to different seed size and weight, seed rate often may vary with mungbean varieties which significantly 
Rahman et al.

influence yield of mungbean (Taj et al., 2003). For machine seeding, it is important to adjust appropriate seed rate of mungbean for different varieties under strip tillage system. Therefore, the study was taken to examine the performance of mungbean varieties under strip tillage system and to determine the optimum seeding rate for those varieties to obtain maximum yield.

\section{Materials and Methods}

The study was conducted at the Agronomy Field Laboratory, Bangladesh Agricultural University, Mymensingh from March to June 2013. The experimental site is located at $24^{\circ} 75^{\prime}$ $\mathrm{N}$ latitude and $90^{\circ} 50^{\prime} \mathrm{E}$ longitude in the south-west part of Brahmaputra at an elevation of 18 $\mathrm{m}$ above the sea level. The site belongs to non-calcareous dark grey floodplain soil under the agro-ecological zone Old Brahmaputra Floodplain "AEZ-9" (UNDP and FAO, 1988). The experimental field was well drained medium high land with silt loam soil in texture having soil $\mathrm{pH}$ of 6.8. The organic matter content of the experimental field was $1.3 \%$. The climate of the experimental site was under the subtropical region characterized by high temperature, high relatively humidity and heavy rainfall with occasional gusty winds during the experimental period. Climate data during the study period were presented in Table 1.

Three promising mungbean varieties viz. BARI Mung-6, Binamung-5 and Bina mung-8 were evaluated against five seed rates $\left(20,25,30,35\right.$ and $\left.40 \mathrm{~kg} \mathrm{ha}^{-1}\right)$ in a split-plot design with three replications. Seeds of three mungbean varieties were sown in the experimental field by a two wheel tractor machine named versatile multi-crop planter (VMP) maintaining the seed rates as per experimental specification. Before one week of sowing the seeds, the preplanting herbicide Roundup® (glyphosate) was applied in the whole field @ $75 \mathrm{~mL} / 10 \mathrm{~L}$ water. Seeds of mungbean were inoculated by Rhizobial bio-fertilizer @ $100 \mathrm{~g} \mathrm{~kg}^{-1}$ of seeds just before sowing. Di-ammonium phosphate (DAP) and muriate of potash (MP) were applied to supply of phosphorus and potassium @ 80 and $40 \mathrm{~kg} \mathrm{ha}^{-1}$, respectively during along with sowing seed on 27 March 2013 by VMP. Seeds were placed by VMP at about 3-4 $\mathrm{cm}$ depth from the soil surface apart from $30 \mathrm{~cm}$ to row distance. Number of weed population was counted randomly selected 2 spots of $1 \mathrm{~m}^{2}$ area. After counting, weeds were cut at the level of ground, cleaned with fresh water and dried in oven at $60^{\circ} \mathrm{C}$ for 72 hours. At maturity, pods were harvested from 02 June to 23 June, 2013. The data on number of plants $\mathrm{m}^{-2}$, plant height, total number of pods plant ${ }^{-1}$, pod length, number of seeds pod ${ }^{-1}$ were recorded from randomly selected five plants from outside of the harvested area. Collected data were analysed and means were compared by Duncan's Multiple Range Test (DMRT) using statistical program MSTAT-C.

Table 1. Monthly record of air temperature, rainfall and relative humidity of the experimental site during March to June 2013

\begin{tabular}{l|c|c|c|c|c}
\hline \multirow{2}{*}{ Months } & \multicolumn{2}{|c|}{ Average air temperature $\left({ }^{\circ} \mathrm{C}\right)$} & \multirow{2}{*}{$\begin{array}{c}\text { Total rainfall } \\
(\mathrm{mm})\end{array}$} & $\begin{array}{c}\text { Average relative } \\
\text { humidity (\%) }\end{array}$ \\
\cline { 2 - 3 } & Max. & Min. & Mean & & \\
\hline March'13 & 31.9 & 19.6 & 25.6 & 21.0 & 73.9 \\
April'13 & 32.5 & 22.5 & 27.5 & 68.2 & 77.2 \\
May'13 & 30.4 & 23.9 & 27.2 & 282.9 & 84.5 \\
June'13 & 33.1 & 26.5 & 29.8 & 236.2 & 82.1 \\
\hline
\end{tabular}

Source: Weather Yard, Department of Irrigation and Water management, BAU, Mymensingh

Results and Discussions 


\section{Plant population}

Plant population of mungbean at 20 days after sowing (DAS) was significantly affected by variety, seed rate and their interaction (Figure $1 \mathrm{a}, 1 \mathrm{~b}$ and 2 ). Among the three varieties, the highest number of plant population (70.80) was obtained from Bina mung-5 while the lowest value (39.93) from BARI Mung-6. In case of five seed rates, the highest number of plant population (89.78) was observed in $40 \mathrm{Kg}$ seed ha ${ }^{-1}$ seed rate whereas the lowest number of plant population (23.78) from $20 \mathrm{Kg}$ seed ha ${ }^{-1}$. From the interaction, the highest number of plant population was found from Bina mung-5 seeding at $40 \mathrm{Kg} \mathrm{ha}^{-1}$ rate and the lowest number of plant population was counted from BARI Mung- 6 at $20 \mathrm{Kg}$ seed $\mathrm{ha}^{-1}$ Therefore, $^{-}$ the study results indicated that plant population of mungbean increased with increasing seed rate. Dainavizadeh and Mehranzadeh (2013) also agreed that plant population increased significantly with increasing seed rate of mungbean.

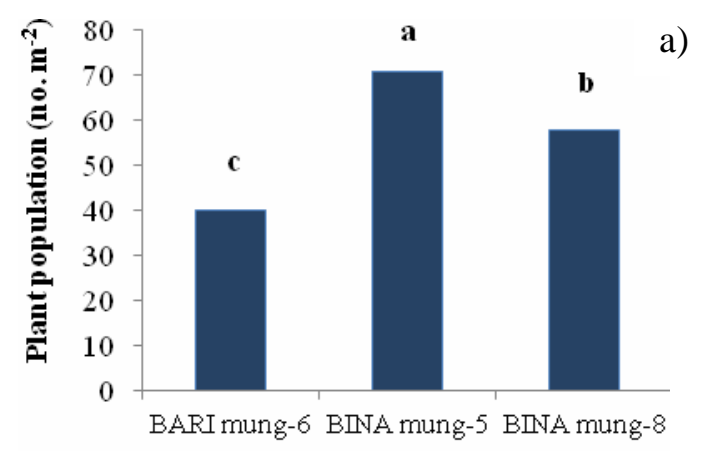

Variety

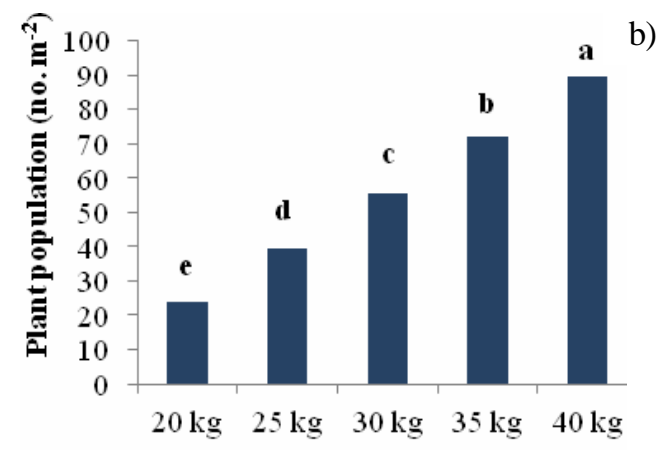

Seed rate (kg ha-1)

Fig. 1. Effect of (a) variety and (b) seed rate on plant population at 20 days after sowing of mungbean under strip tillage system

\section{Yield and yield contributing characters}

Yield contributing characters like number of pods plant ${ }^{-1}$, pod length, number of seeds pod ${ }^{-1}$ and 1000-seed weight were significantly affected by variety and seed rate of mungbean as well as seed and stover yields (Table 2 and 3 ). The highest number of pods plant ${ }^{-1}$ (40.73), pod length $(8.08 \mathrm{~cm})$, seed yield $\left(888.17 \mathrm{~kg} \mathrm{ha}^{-1}\right)$ and stover yield $\left(1874.25 \mathrm{~kg} \mathrm{ha}^{-1}\right)$ were obtained from Bina mung-5. Whilst, the highest number of seeds pod $^{-1}(9.68)$ and 1000 -seed weight (37.14) were obtained from BARI Mung-6. In case of seed rate, the highest number of pods plant ${ }^{-1}$ (40.3) was counted from $20 \mathrm{~kg} \mathrm{seed} \mathrm{ha}^{-1}$ and the lowest value (33.0) from $40 \mathrm{~kg}$ seed $\mathrm{ha}^{-1}$. This might be happened due to the variation in number of plant population. Low plant population may influence to produce more pods plant ${ }^{-1}$ and therefore, the inverse result can be found in case of high plant population of mungbean. Similar results reported by Taj et al. (2003) and Mackenzie (1985) that number of pods per plant decreased in mungbean with increasing number of plant population. On the other hand, the highest pod length $(8.46 \mathrm{~cm})$, number of seeds pod $^{-1}(9.68), 1000$-grain weight $(35.13 \mathrm{~g})$ and seed yield $\left(807.31 \mathrm{~kg} \mathrm{ha}^{-1}\right)$ were recorded from $35 \mathrm{~kg}$ seed ha ${ }^{-1}$.Similar results were also found in $40 \mathrm{~kg}$ seed ha-1.These results are in contrast with Taj et al. (2003) who found that the number of seeds pod ${ }^{-1}$ and 1000 -seed weight decreased with increasing seed rate. The highest stover yield was obtained from $40 \mathrm{~kg}$ seed ha-1 that might be due to highest plant population at $40 \mathrm{~kg}$ seed $\mathrm{ha}^{-1}$. However, the maximum seed yield was obtained from $35 \mathrm{~kg}$ seed ha ${ }^{-1}\left(807.31 \mathrm{~kg} \mathrm{ha}^{1}\right)$ which was closely followed by $40 \mathrm{~kg}$ seed ha ${ }^{-1}\left(806.52 \mathrm{~kg} \mathrm{ha}^{1}\right)$. Jahan and Hamid (2004) 
Rahman et al.

also reported that significant variation in number of pods palnt ${ }^{-1}$ and seeds pod ${ }^{-1}$ due to difference in population density caused the variation in seed yield.

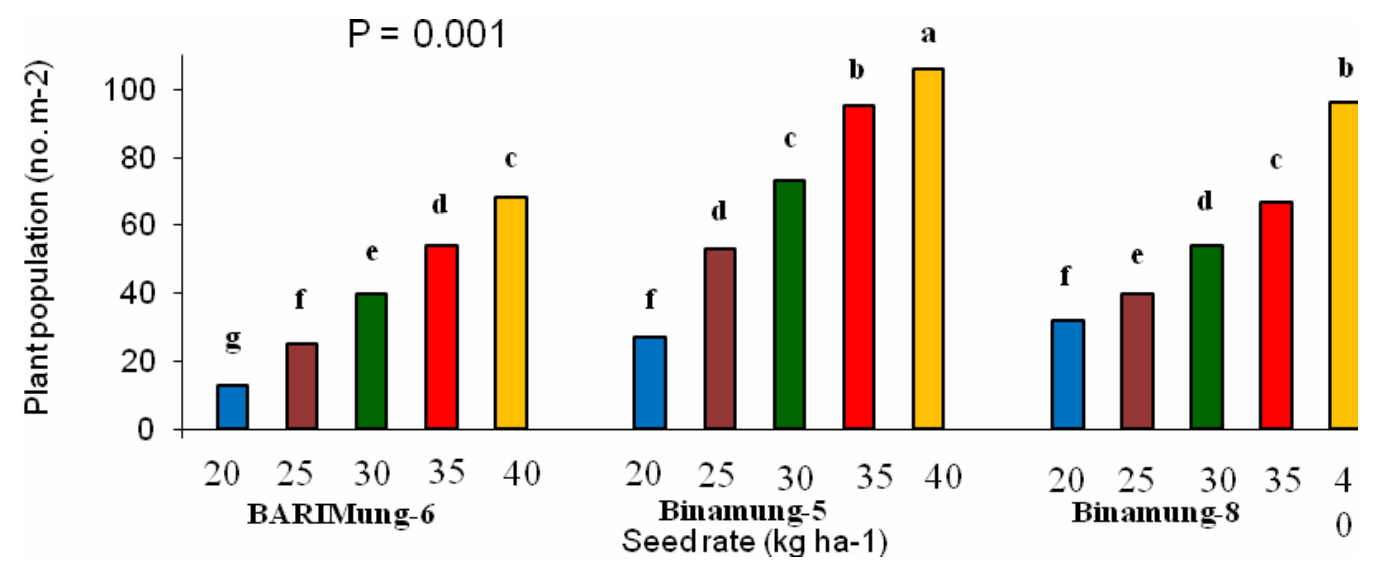

Fig. 2. Interaction effect of variety and seed rate on plant population at 20 DAS mungbean under strip tillage system

Table 2. Effect of variety on yield and yield contributing characters of mungbean under strip tillage system

\begin{tabular}{|c|c|c|c|c|c|c|}
\hline Variety & $\begin{array}{l}\text { Number of } \\
\text { Pods plant }^{-1}\end{array}$ & $\begin{array}{l}\text { Pod length } \\
\text { (cm) }\end{array}$ & $\begin{array}{l}\text { Number of } \\
\text { Seeds pod }\end{array}$ & $\begin{array}{c}1000- \\
\text { seed wt. } \\
\text { (g) }\end{array}$ & $\begin{array}{c}\text { Seed yield } \\
\left(\mathrm{kg} \mathrm{ha}^{-1}\right)\end{array}$ & $\begin{array}{l}\text { Stover yield } \\
\left(\mathrm{kg} \mathrm{ha}^{-1}\right)\end{array}$ \\
\hline BARIMung-6 & $34.53 \mathrm{~b}$ & $7.96 \mathrm{~b}$ & $9.68 \mathrm{a}$ & $37.14 \mathrm{a}$ & $506.56 \mathrm{~b}$ & $1026.00 \mathrm{~b}$ \\
\hline Bina Mung-5 & $40.73 \mathrm{a}$ & $8.08 \mathrm{a}$ & $9.61 \mathrm{a}$ & $32.20 \mathrm{~b}$ & $888.17 \mathrm{a}$ & $1874.25 \mathrm{a}$ \\
\hline Bina Mung-8 & $35.20 \mathrm{~b}$ & $7.75 \mathrm{c}$ & $7.716 \mathrm{~b}$ & $31.02 \mathrm{c}$ & $429.80 \mathrm{c}$ & $890.55 \mathrm{c}$ \\
\hline $\operatorname{LSD}_{(0.05)}$ & 2.63 & 0.11 & 0.34 & 1.88 & 15.77 & 30.60 \\
\hline CV $(\%)$ & 2.96 & 1.58 & 3.03 & 1.78 & 4.87 & 3.18 \\
\hline
\end{tabular}

In a column figures with same letters do not differ significantly whereas figures with dissimilar letters differ significantly (as per DMRT).

In case of interaction effect of variety and seed rate, number of pods plant ${ }^{-1}$, pod length, number seeds pod $^{-1}$, seed yield and stover yield of mungbean were also significantly varied with treatments except 1000-grain weight (Table 4). The highest number of pods plant ${ }^{-1}$ (44.0) was counted from Bina mung-5 at $20 \mathrm{~kg} \mathrm{ha}^{-1}$ but, the highest pod length $(8.79 \mathrm{~cm})$ with higher number of seeds pod $^{-1}$ were obtained from Bina mung-5 sowing at $35 \mathrm{~kg}$ seed $\mathrm{ha}^{-1}$ resulting the highest seed yield $\left(1215.35 \mathrm{~kg} \mathrm{ha}^{-1}\right)$. While the highest stover yield $\left(2506.12 \mathrm{~kg} \mathrm{ha}^{-1}\right)$ was found from Bina mung-5 at $40 \mathrm{~kg}$ seed ha ${ }^{-1}$ because of having the highest number of plant population. In case of BARI Mung-6, $35 \mathrm{~kg}$ seed ha ${ }^{-1}$ also produced higher seed yield compare to other seed rates because of producing the highest number of seeds pod $^{-1}$ (10.8). Therefore, the results showed that BARI Mung- 6 , Bina mung-5 and Bina mung- 8 gave their highest seed yield at $35 \mathrm{~kg}$ seed ha ${ }^{-1}$ but all varieties produced highest stover yield at $40 \mathrm{~kg}$ seed ha ${ }^{-1}$. Singh et al. (2003), Hasan (2004) and Chowdhury (1999) also reported that seed yield of mungbean increased with increasing seed rate up to certain levels and thereafter decreased. On the other hand, all varieties gave the lowest yield (seed and stover) at $20 \mathrm{~kg}$ seed ha ${ }^{-1}$ and resulted less number of plant populations as a result the less number of seeds were produced per pods with the short pod length. 
Effect of Variety and Seed Rate on Yield Performance of Mungbean under Strip Tillage System

Table 3. Effect of seed rate on yield and yield contributing characters of mungbean under strip tillage system

\begin{tabular}{c|c|c|c|c|c|c}
\hline $\begin{array}{c}\text { Seed rate } \\
\left(\mathrm{kg} \mathrm{ha}^{-1}\right)\end{array}$ & $\begin{array}{c}\text { Number of } \\
\text { pods plant }^{-1}\end{array}$ & $\begin{array}{c}\text { Pod length } \\
(\mathrm{cm})\end{array}$ & $\begin{array}{c}\text { Number of } \\
\text { seeds pod }\end{array}$ & $\begin{array}{c}1000- \\
\text { seed wt. } \\
(\mathrm{g})\end{array}$ & $\begin{array}{c}\text { Seed yield } \\
\left(\mathrm{kg} \mathrm{ha}^{-1}\right)\end{array}$ & $\begin{array}{c}\text { Stover yield } \\
\left(\mathrm{kg} \mathrm{ha}^{1}\right)\end{array}$ \\
\hline 20 & $40.33 \mathrm{a}$ & $7.35 \mathrm{e}$ & $7.72 \mathrm{~d}$ & $31.72 \mathrm{~b}$ & $316.90 \mathrm{~d}$ & $807.00 \mathrm{e}$ \\
25 & $38.22 \mathrm{ab}$ & $7.66 \mathrm{~d}$ & $8.60 \mathrm{c}$ & $32.7 \mathrm{ab}$ & $501.90 \mathrm{c}$ & $1094.16 \mathrm{~d}$ \\
30 & $37.00 \mathrm{ab}$ & $7.86 \mathrm{c}$ & $8.82 \mathrm{bc}$ & $33.62 \mathrm{ab}$ & $608.12 \mathrm{~b}$ & $1225.07 \mathrm{c}$ \\
35 & $35.56 \mathrm{bc}$ & $8.46 \mathrm{a}$ & $9.68 \mathrm{a}$ & $35.13 \mathrm{a}$ & $807.31 \mathrm{a}$ & $1440.00 \mathrm{~b}$ \\
40 & $33.00 \mathrm{c}$ & $8.31 \mathrm{~b}$ & $9.25 \mathrm{ab}$ & $34.13 \mathrm{ab}$ & $806.52 \mathrm{a}$ & $1751.00 \mathrm{a}$ \\
\hline $\mathrm{LSD}_{(0.05)}$ & 3.39 & 0.14 & 0.44 & 2.43 & 20.36 & 39.51 \\
$\mathrm{CV}(\%)$ & 2.96 & 1.58 & 3.03 & 1.78 & 4.87 & 3.18 \\
\hline
\end{tabular}

In a column figures with same letters do not differ significantly whereas figures with dissimilar letters differ significantly (as per DMRT).

\section{Conclusion}

The study results expressed that among the three mungbean varieties, the performance of Bina mung- 5 was superior as it produced the highest seed yield at $35 \mathrm{~kg}$ seed ha ${ }^{-1}$. In case of BARI Mung- 6 and Bina mung- $8,35 \mathrm{~kg}$ seed ha ${ }^{-1}$ also helped to obtain their maximum seed yield. The study also expressed that seeding rate more than $35 \mathrm{~kg} \mathrm{ha}^{-1}$ increased stover yield but decreased seed yield where Bina mung-8 at $20 \mathrm{~kg}$ seed ha ${ }^{-1}$ produced the lowest seed and stover yield in this system.

Table 4. Interaction effect of variety and seed rate on yield and yield contributing characters of mungbean under strip tillage system

\begin{tabular}{|c|c|c|c|c|c|c|c|}
\hline \multicolumn{2}{|c|}{$\begin{array}{c}\text { Variety } \times \text { Seed rate } \\
\left(\mathrm{kg} \mathrm{ha}^{-1}\right)\end{array}$} & $\begin{array}{l}\text { Number of } \\
\text { pods plant }^{-1}\end{array}$ & $\begin{array}{l}\text { Pod length } \\
(\mathrm{cm})\end{array}$ & $\begin{array}{l}\text { Number of } \\
\text { seeds pod }^{-1}\end{array}$ & $\begin{array}{l}\text { 1000-seed } \\
\text { wt. (g) }\end{array}$ & $\begin{array}{l}\text { Seed yield } \\
\left(\mathrm{kg} \mathrm{ha}^{-1}\right)\end{array}$ & $\begin{array}{l}\text { Stover yield } \\
\left(\mathrm{kg} \mathrm{ha}^{-1}\right)\end{array}$ \\
\hline BARI & 20 & $38.3 \mathrm{de}$ & $7.52 \mathrm{~g}$ & $8.2 \mathrm{de}$ & 35.16 & $191.15 \mathrm{k}$ & $430.47 \mathrm{k}$ \\
\hline \multirow[t]{4}{*}{ Mung- 6} & 25 & $35.7 \mathrm{fg}$ & $7.75 \mathrm{fg}$ & $9.5 \mathrm{c}$ & 36.14 & 389.74 i & $854.80 \mathrm{~h}$ \\
\hline & 30 & $34.0 \mathrm{gh}$ & $8.00 \mathrm{de}$ & $9.8 \mathrm{bc}$ & 37.47 & $521.70 \mathrm{~g}$ & $1072.34 \mathrm{~g}$ \\
\hline & 35 & $33.7 \mathrm{~h}$ & $8.33 \mathrm{~b}$ & $10.8 \mathrm{a}$ & 39.19 & $730.12 \mathrm{e}$ & $1324.17 f$ \\
\hline & 40 & $31.0 \mathrm{j}$ & $8.19 \mathrm{bcd}$ & $10.1 \mathrm{~b}$ & 37.74 & $700.30 \mathrm{e}$ & $1449.34 \mathrm{e}$ \\
\hline \multirow{5}{*}{$\begin{array}{l}\text { Bina } \\
\text { mung-5 }\end{array}$} & 20 & $44.0 \mathrm{a}$ & $7.28 \mathrm{~h}$ & $8.7 \mathrm{~d}$ & 30.56 & $460.63 \mathrm{~h}$ & $1307.05 \mathrm{f}$ \\
\hline & 25 & $42.3 a b$ & $7.70 \mathrm{~g}$ & $9.5 \mathrm{c}$ & 31.14 & $787.08 \mathrm{~d}$ & $1663.49 \mathrm{~d}$ \\
\hline & 30 & $41.3 b c$ & 7.94 ef & $9.7 \mathrm{bc}$ & 32.16 & $876.30 \mathrm{c}$ & $1769.87 \mathrm{c}$ \\
\hline & 35 & $39.7 \mathrm{~cd}$ & $8.79 \mathrm{a}$ & $10.2 b$ & 34.00 & $1215.35 \mathrm{a}$ & $2124.21 \mathrm{~b}$ \\
\hline & 40 & $36.3 \mathrm{f}$ & $8.69 \mathrm{a}$ & $10.0 \mathrm{~b}$ & 33.15 & $1102.41 \mathrm{~b}$ & $2506.12 \mathrm{a}$ \\
\hline \multirow{5}{*}{$\begin{array}{l}\text { Bina } \\
\text { mung-8 }\end{array}$} & 20 & $38.7 \mathrm{~d}$ & $7.26 \mathrm{~h}$ & $6.3 \mathrm{~h}$ & 29.44 & $299.20 \mathrm{j}$ & $683.70 \mathrm{j}$ \\
\hline & 25 & 36.7 ef & $7.53 \mathrm{~g}$ & $6.8 \mathrm{~g}$ & 30.73 & $329.10 \mathrm{j}$ & $765.10 \mathrm{i}$ \\
\hline & 30 & $35.7 \mathrm{fg}$ & $7.64 \mathrm{~g}$ & $7.0 \mathrm{~g}$ & 31.24 & $426.43 \mathrm{hi}$ & $832.95 \mathrm{~h}$ \\
\hline & 35 & $33.3 \mathrm{hi}$ & $8.26 \mathrm{bc}$ & $7.6 \mathrm{f}$ & 32.19 & $619.36 \mathrm{f}$ & $873.30 \mathrm{~h}$ \\
\hline & 40 & $31.7 \mathrm{ij}$ & 8.04 cde & $8.1 \mathrm{e}$ & 31.50 & $475.07 \mathrm{gh}$ & $1297.48 \mathrm{f}$ \\
\hline \multirow{2}{*}{\multicolumn{2}{|c|}{$\begin{array}{l}\text { LSD (0.050 } \\
\text { CV (\%) }\end{array}$}} & & 0.21 & 0.45 & 1.00 & 49.95 & 67.68 \\
\hline & & 2.96 & 1.58 & 3.03 & 1.78 & 4.87 & 3.18 \\
\hline
\end{tabular}

In a column figures with same letters do not differ significantly (as per DMRT).

\section{References}

BBS. 2016. Statistical Year Book Bangladesh 2014. p: 113. 
Rahman et al.

Bonari, E., and M. Macchia. 1975. Effect of plant density on yield of bean (Vicia faba) minor, spacing back. Indian J. Plant Physiol. 204: 119-121.

Chowdury, A. S. 1999. Effect of seed rate and weeding regime on the yield and yield contributing characters of summer mungbean. MS Thesis, Dept. of Agron., BAU, Mymensingh. p: 38.

Dainavizadeh, P. and M. Mehranzadeh. 2013. Effect of seed rate on growth, yield components and yield of mungbean growth under irrigated conditions in the north of Khuzestan. Int. J. Agric. Crop Sci. 5(20): 2359-2364.

Endres, G. and P. Hendrickson. 2010. Row crop performance with tillage systems and placement of fertilizer. In: Carrington Research Extension Center Annual Report. Vol. 15.v

Hasan, S. M. M. 2004. Effect of seed rate on the yield and quality of mungbean. MS Thesis, Dept. of Agron., BAU, Mymensingh. p: 39.

Jahan, M. S. and A. Hamid. 2004. Effect of population density and planting configuration on dry matter allocation and yield of mungbean (Vigna radiate (L.) Wilczek). Pakistan J. Biol. Sci. 7(9): 1493-1498.

Mackenzie, D. R. and T. D. Lious. 1985. Response of mungbean and soybean (Glycine max $\mathrm{L}$ Mirr) to increasing plant density. Am. Society Hort. Sci. 100: 579-583.

MOA (Ministry of Agriculture). 2012. Hand book of agricultural statistics. Ministry of Agriculture, Government of People's Republic Bangladesh, Dhaka. P. 27.

Nowatzki, J., G. Endres, J. Dejong-Hughes and D. Aakre. 2011. Strip till for field crop protection. Available at: www.ag.ndsu.edu

Shanmugasundaram, S., J. D. H. Keatinge and J. Hughes. 2009. Counting on Beans: Mungbean Improvement in Asia. In: Spielman D. J., and R. Pandya-Lorch (eds.) Millions fed: Proven Successes in Agricultural Development, IFPRI, Washington DC.

Singh, G., H. S. Sekhon, J. S. Sandhu, S. J. Singh, R. K. Gumber and A. S. Randhawa. 2003. Effect of location and seed rate on three genotypes of mungbean. Trop Sci 43: 116-120.

Taj, F. H., M. Arif and K. M. Kakar. 2003. Effect of seed rates on mungbean varieties under dryland conditions. Int. J. Agric. Biol. 5(1): 160-161.

UNDP and FAO. 1988. Agro-ecological region of Bangladesh. Land resources appraisal of Bangladesh for agricultural development. United Nations Development Programme and Food and Agricultural Organization. BGD/81/035, Tech. Rep. N2, FAO and UNDP. Pp: 212-221. 